\title{
The Formation of Free Standing NiO Nanostructures on Nickel Foam for Supercapacitors
}

\author{
F.E. Atalay, E. Aydogmus, H. Yigit, D. Avcu, H. Kaya and S. Atalay \\ Inonu University, Science and Art Faculty, Department of Physics, Malatya 44280, Turkey
}

\begin{abstract}
In this study, free standing $\mathrm{NiO}$ nanostructures for supercapacitors were obtained by means of chemically depositing of nickel oxide on $\mathrm{Ni}$ foam and then they were annealed at various temperatures. The morphological properties of densely covered $\mathrm{Ni}$ foams were studied by scanning electron microscopy. Supercapacitor characteristics, such as charging/discharging and impedance characteristics, were also examined.
\end{abstract}

DOI: $10.12693 /$ APhysPolA.125.224

PACS: 81.07.-b, 82.47.Uv, 88.80.fh

\section{Introduction}

Capacitors have been studied intensively to store electrical energy in the last thirty years. There have been many studies on this topic such as: electrode type, shape, available electrode materials, especially with the electrochemical reduction and oxidation processes. Generally, the desired electrodes, which usually contain nanoparticles, have high surface area and high energy density. In addition, the other important features for supercapacitors and batteries are long life, low cost and stability.

In recent years, carbon aerogel, activated carbon, carbon nanotubes, conductive polymers, and various metal oxide structures have been investigated as a supercapacitor electrode material [1-6].

In the present study, chemically deposited $\mathrm{NiO}$ nanostructures on $\mathrm{Ni}$ foams were produced and then employed as the electro-active materials for the supercapacitor. The highest specific capacitance, $329 \mathrm{~F} / \mathrm{g}$, was observed at constant current-discharge with a current density $0.2 \mathrm{~A} / \mathrm{g}$ in $6 \mathrm{M} \mathrm{KOH}$.

\section{Experimental}

To obtain $\mathrm{NiO}$ nanostructures on $\mathrm{Ni}$ foam, first $\mathrm{Ni}$ foams were degreased with acetone, etched with $3 \mathrm{M}$ $\mathrm{HCl}$ for 10 min and then washed thoroughly with deionized water, later acetone, again deionized water. $1.15 \mathrm{~g}$ $\mathrm{Ni}\left(\mathrm{NO}_{3}\right)_{2}, 2.9 \mathrm{~g}$ urea, and $40 \mathrm{ml}$ ethanol solution was mixed, then this solution was completed to $100 \mathrm{ml}$ by adding water. Then the Ni foams were vertically dipped into the solution at $90^{\circ} \mathrm{C}$ in a vacuum oven for the different times $(4 \mathrm{~h}, 8 \mathrm{~h}, 12 \mathrm{~h})$. Finally, foams were removed from the solvent and dried in the vacuum oven at $60^{\circ} \mathrm{C}$ for $30 \mathrm{~min}$. The formed nanostructures on $\mathrm{Ni}$ foam were heated from room temperature to various annealing temperatures $\left(250{ }^{\circ} \mathrm{C}, 275^{\circ} \mathrm{C}, 300^{\circ} \mathrm{C}, 360^{\circ} \mathrm{C}\right)$ in air at a rate of $2{ }^{\circ} \mathrm{C} / \mathrm{min}$ and maintained for $2 \mathrm{~h}$. This was followed by cooling to room temperature at a rate of $10^{\circ} \mathrm{C} / \mathrm{min}$. The obtained material was used as a cathode, with an exposed area of approximately $1 \mathrm{~cm}^{2}$ for the capacitance measurement. A three-electrode cell was used for the electro- chemical experiments. The volume of the electrochemical bath was approximately $60 \mathrm{ml}$. $\mathrm{An} \mathrm{Ag} / \mathrm{AgCl}$ ceramic electrode (BAS, saturated $\mathrm{KCl}$, and $-42 \mathrm{mV}$ versus $\mathrm{SCE}$ at $25^{\circ} \mathrm{C}$ ) was used as the reference electrode. A platinum electrode approximately $1 \mathrm{~cm}^{2}$ was used as an auxiliary electrode. The electrolyte used was $6 \mathrm{M} \mathrm{KOH}$. CV (cyclic voltammograms), charge-discharge and electrochemical impedance spectroscopy (EIS) measurements were performed using an electrochemical analyzer system, namely an Iviumstat potentiostat/galvanostat. The frequency limits were typically set between $10 \mathrm{mHz}$ and $100 \mathrm{kHz}$. The AC oscillation amplitude was $5 \mathrm{mV}$. The morphology of the nanostructures was investigated by scanning electron microscopy (SEM; JEOL JSEM 7001F).

\section{Results and discussion}

The morphologies of the $\mathrm{NiO}$ nanostructures grown on $\mathrm{Ni}$ foam in the solution for $8 \mathrm{~h}$ are shown in Fig. 1. The annealing temperature effect can be obviously seen from Fig. 1. The nanothorny structure was observed for $250^{\circ} \mathrm{C}$ annealed sample. There was also observed the nanowall structure for the sample annealed at $300^{\circ} \mathrm{C}$. It is worth noting that the specific surface area increases with the increasing annealing temperature. So the capacitance value also increases.

The electrochemical characteristics of the $\mathrm{NiO}$ nanostructures on nickel foam electrodes annealed at different temperatures were studied using cyclic voltammetry with $6.0 \mathrm{M} \mathrm{KOH}$ as the electrolyte, over the voltage range $-0.5 \mathrm{~V}$ to $+0.5 \mathrm{~V}$ (vs. $\mathrm{Ag} / \mathrm{AgCl}$ ) at $5-100 \mathrm{mV} / \mathrm{s}$ scan rates. Typical CVs of electrodes of samples annealed at different temperatures are shown in Fig. 2. The inset of Fig. 2 shows CV of only nickel foam electrode and $\mathrm{NiO}$ nanostructures on $\mathrm{Ni}$ foam electrode, both samples were annealed at $300^{\circ} \mathrm{C}$. There was a weak signal from $\mathrm{Ni}$ foam electrode compared to the $\mathrm{NiO}$ nanostructures on nickel foam. The ideal rectangular CV curve shape was not observed for all samples. This mainly results from that the pseudocapacitance occurred from redox mechanism. The estimated specific capacitances from the CVs by integrating the area under the current-potential 


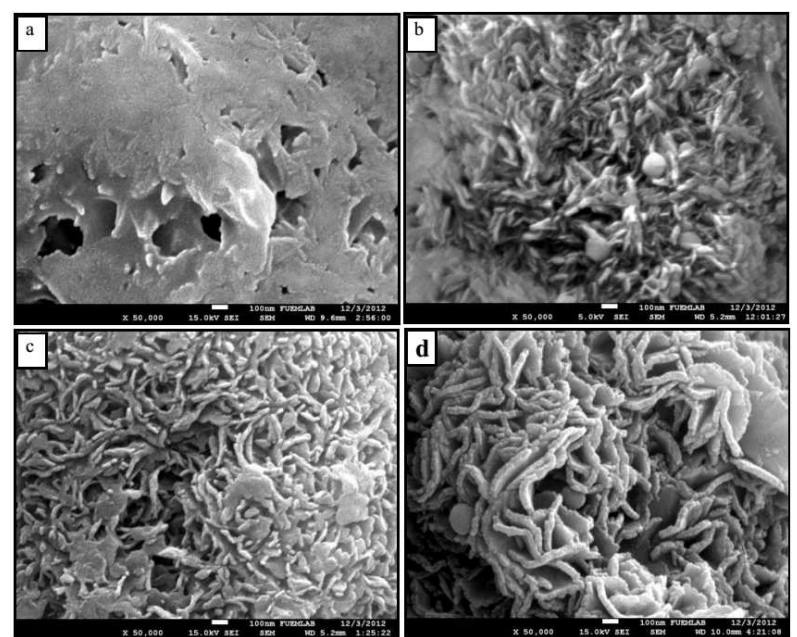

Fig. 1. SEM images of $\mathrm{NiO}$ nanostructures on $\mathrm{Ni}$ foam at various annealing temperatures: (a) as received, (b) $250{ }^{\circ} \mathrm{C}$, (c) $275^{\circ} \mathrm{C}$, (d) $300^{\circ} \mathrm{C}$.

curve for the electrodes annealed at $300^{\circ} \mathrm{C}$ and $360^{\circ} \mathrm{C}$ were higher than the other electrodes. So, electrochemical properties of these electrodes are further discussed in the following part.

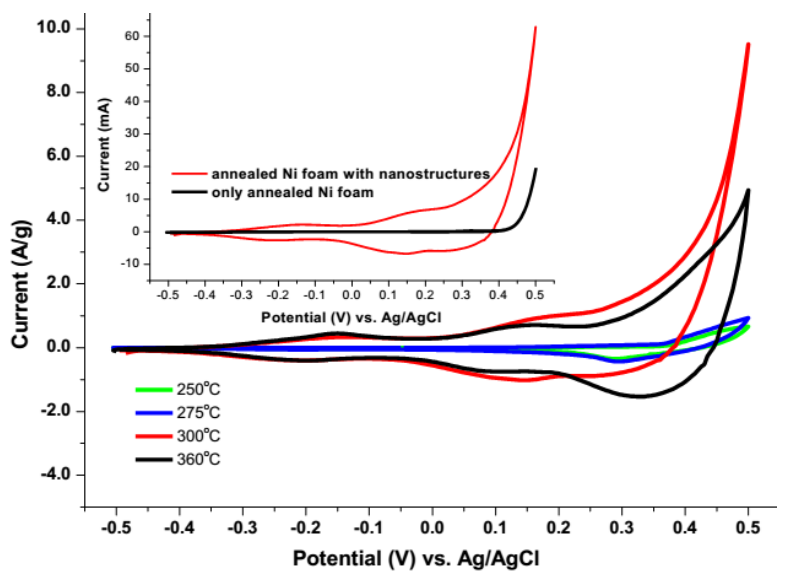

Fig. 2. Cyclic voltammograms of $\mathrm{NiO}$ nanostructure annealed at different temperatures in $6 \mathrm{M} \mathrm{KOH}$ solution. Inset shows the $\mathrm{CV}$ comparations of $\mathrm{Ni}$ foam and $\mathrm{NiO}$ nanostructures on $\mathrm{Ni}$ foam. Scan rate is $5 \mathrm{mV} / \mathrm{s}$.

The inset of Fig. 3 shows the ten cyclic chargedischarge curves of heated to $300^{\circ} \mathrm{C}$ sample at $0.2 \mathrm{~A} / \mathrm{g}$ over the operating potential range $0-0.38 \mathrm{~V}$ (vs. $\mathrm{Ag} / \mathrm{AgCl}$ ). The discharge current curves are almost linear in the total range of potential, which shows a very good capacitive behavior [7-9]. The specific capacitance values can be calculated from the following formula [3]:

$$
C_{\mathrm{s}}=\frac{I \times \Delta t}{m \times \Delta V},
$$

where $C_{\mathrm{S}}$ is the specific discharge capacitance, $I$ is the discharge current, $\Delta t$ is the discharge time, $\Delta V$ is the potential drop in the discharge progress and $m$ is the active mass of the electrode (including only the mass of the $\mathrm{NiO}$, not the Ni foam). The long term galvanostatic cycling stability of $\mathrm{NiO}$ nanostructures on Ni foam electrodes were investigated over 1000 cycles (Fig. 3). The capacitance of electrodes slowly reduces from $329 \mathrm{~F} / \mathrm{g}$ and $286 \mathrm{~F} / \mathrm{g}$ during the first 200 cycles and then reaches to the stable value of $285 \mathrm{~F} / \mathrm{g}$ and $240 \mathrm{~F} / \mathrm{g}$ for $300^{\circ} \mathrm{C}$ and $360^{\circ} \mathrm{C}$, respectively. Voltammetric and galvanostatic results indicate that the nanoporous structure and large surface area on the $\mathrm{Ni}$ foam and also presence of $\mathrm{NiO}$ nanowalls play are mainly responsible for obtaining optimum capacitance values. The charge-discharge efficiency is $87 \%$ for nanowall-like $\mathrm{NiO}$ electrodes after 1000 charge/ discharge cycles.

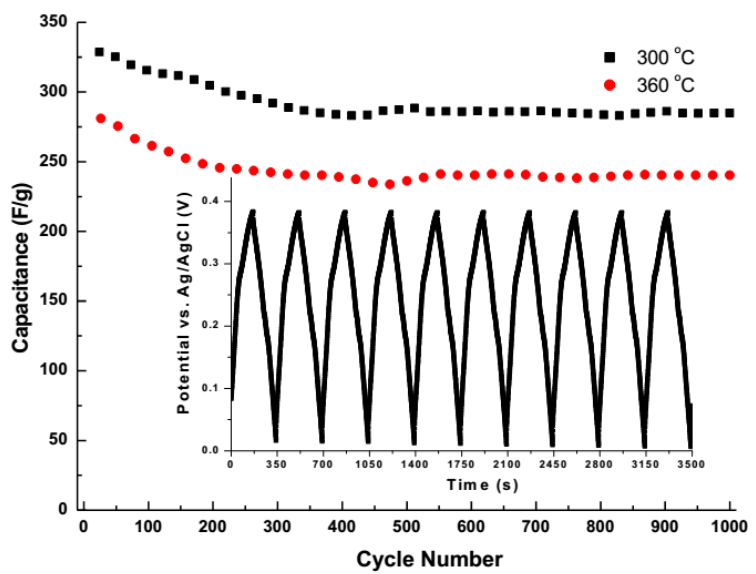

Fig. 3. The variation of specific capacitance as a function of cycle number of $\mathrm{NiO}$ electrodes. The inset shows the chronopotentiograms of $\mathrm{NiO}$ electrode annealed at $300{ }^{\circ} \mathrm{C}$.

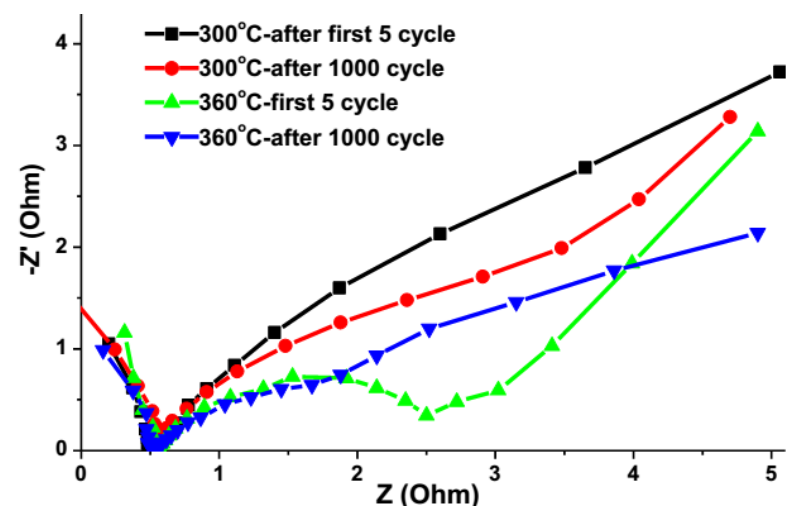

Fig. 4. Nyquist plots of $\mathrm{NiO}$ electrode heated to $300{ }^{\circ} \mathrm{C}$ and $360{ }^{\circ} \mathrm{C}$ at $0.2 \mathrm{~A} / \mathrm{g}$ in $6 \mathrm{M} \mathrm{KOH}$ solution.

Figure 4 displays the Nyquist plots of the $\mathrm{AC}$ impedance of the $\mathrm{NiO}$ nanostructured electrodes for $300{ }^{\circ} \mathrm{C}$ and $360{ }^{\circ} \mathrm{C}$ (frequency range, $100 \mathrm{kHz}-10 \mathrm{mHz}$ ) at open circuit potential. These impedance plots were measured after 5 or 1000 continuous charge and discharge 
cycles. After 1000 continuous cycles, $58^{\circ}$ straight line of sample annealed at $300{ }^{\circ} \mathrm{C}$ at the low frequency range demonstrates a good capacitive feature, that is the typical characteristic of porous electrodes.

\section{Conclusion}

In this work, free standing $\mathrm{NiO}$ nanostructures on $\mathrm{Ni}$ foams were chemically deposited without need for mixing and pressing powders. These free standing nanostructures were employed as the electro-active materials for the supercapacitor. Voltammetric and galvanostatic results indicate that the nanoporous structure and large surface area of the $\mathrm{Ni}$ foam and also presence of $\mathrm{NiO}$ nanowalls play are mainly responsible for obtaining optimum capacitance values. The obtained discharge current curves for $300^{\circ} \mathrm{C}$ annealed sample are almost linear in the total range of potential, which shows a very good capacitive behavior. The columbic efficiency remains above $87 \%$ within 1000 cycles.

\section{Acknowledgments}

This work was supported by Inonu University with project number I.U.A.F-2013/78.

\section{References}

[1] R. Kötz, M. Carlen, Electrochim. Acta 45, 2483 (2000).

[2] X. Qing, S. Liu, K. Huang, K. Lv, Y. Yang, Z. Lu, D. Fang, X. Liang, Electrochim. Acta 56, 4985 (2011).

[3] Y.Y. Gao, S.L. Chen, D.X. Cao, G.L. Wang, J.L. Yin, J. Power Sources 195, 1757 (2010).

[4] J. Xu, L. Gao, J. Cao, W. Wang, Z. Chen, J. Solid State Electrochem. 15, 2005 (2011).

[5] X. Xia, J. Tu, Y. Zhang, Y. Mai, X. Wang, C. Gu, X. Zhao, RCS Adv. 2, 1835 (2012).

[6] V. Yagmur, F.E. Atalay, H. Kaya, D. Avcu, E. Aydogmus, Acta Phys. Pol. A 123, 215 (2013).

[7] B.E. Conway, J. Electrochem. Soc. 138, 1539 (1991).

[8] D. Wei, M.R.J. Scherer, C. Bower, P. Andrew, T. Ryhanen, U. Steiner, Nano Lett. 12, 1857 (2012).

[9] D. Zhao, Z. Yang, L. Zhang, X. Feng, Y. Zhang, Electrochem. Solid-State Lett. 14, A93 (2011). 